\title{
$O$ redefinir das fronteiras dos poderes políticos e religiosos após a Independência do Brasil: o Seminário de Mariana-MG como espaço de conflito
}

\author{
Gabriela Berthou de Almeida* \\ Universidade Estadual de Campinas \\ Campinas - São Paulo - Brasil
}

Entre as décadas de 1820 e 1830, o Seminário de Nossa Senhora da Boa Morte, localizado na sede do bispado de Minas Gerais, foi tomado como foco de disputas políticas, religiosas e educacionais. Dois sujeitos com projeção social na província mineira foram protagonistas dos embates: o bispo Dom Frei José da Santíssima Trindade e o padre, professor e político Antonio José Ribeiro Bhering. O objetivo do artigo é demonstrar como as disputas geradas em torno do Seminário de Mariana, sobretudo as que se referem à definição dos seus Estatutos de regência, estiveram vinculadas a readequação dos campos de atuação dos poderes políticos e religiosos nos anos que sucederam a Independência do Brasil.

\section{Palavras-chave}

Poderes políticos e religiosos; Minas Gerais; Seminário de Mariana; Antonio José Ribeiro Bhering; Dom Frei José da Santíssima Trindade.

* Mestra em História pela Universidade Estadual de Campinas, onde atualmente cursa doutorado. O artigo é resultado de uma pesquisa financiada pelo CNPq e pela FAPESP. Email: gbalmeida87@ gmail.com. 


\section{Abstract}

Between the 1820s and 1830s, the Seminário Nossa Senhora da Boa Morte, located in the home of the Bishop in Minas Gerais, was seized as the focus of political, religious and educational disputes. Two main subjects with great social projection in the province of Minas Gerais performed as leading figures in such conflicts: the Bishop Dom Frei José da Santíssima Trindade and the priest, teacher and politician Antonio José Ribeiro Bhering. The purpose of this paper is to demonstrate how the disputes around Mariana Seminar, most importantly the ones concerning the settling of its regency Statutes, had been bound to the re-adequacy regarding political and religious authorities' fields of practice in the years following the independence of Brazil.

Political and religious authorities; Minas Gerais; Mariana Seminar; Antonio José Ribeiro Bhering; Dom Frei José da Santíssima Trindade. 


\section{Considerações iniciais: o estabelecimento do conflito}

Em outubro de 1829, o jornal $O$ Universal - folha autodesignada liberal e com maior circulação na província de Minas Gerais na primeira metade do século XIX - noticiou em mais de um número, com tom de indignação, a exoneração de Antonio José Ribeiro Bhering do quadro de professores do Seminário de Nossa Senhora da Boa Morte. ${ }^{1}$ Era ele mestre de Filosofia quando recebeu um ofício, datado de 5 de outubro e assinado pelo bispo de Mariana, Dom Frei José da Santíssima Trindade, informando que suas aulas estavam suspensas "por motivos muito poderosos e conhecidos por todos". ${ }^{2}$ Ao reitor do Seminário foi enviado outro documento, no qual era ordenado que fosse tornada pública a resolução aos estudantes que frequentavam o curso. O bispo argumentou que a expulsão foi necessária, pois "ensoberbecido por sua ciência desandou o improvisado lente de Filosofia a pregar em sua cadeira novidades filosóficas", mostrando-se, de tal modo, disposto a corromper os alunos que não lhe restou outra saída senão a de lançá-lo fora. ${ }^{3}$

Antonio José Ribeiro Bhering nasceu em Ouro Preto e pertencia a uma família modesta, que o enviou no início da década de 1820 para estudar no Seminário de Mariana. Foi ordenado padre pelo próprio Dom Frei José, em 1826. No mesmo ano, fora nomeado professor de Filosofia do estabelecimento, sendo demitido do cargo três anos depois. Ele não aceitou a expulsão e empreendeu uma ampla campanha contra a mais alta autoridade religiosa de Minas, exposta a princípio na imprensa, mas que se expandiu para outros espaços, como o Con-

1 Segundo o historiador Wlamir Silva, esse jornal "foi o periódico de referência da capital da província representando o pensamento liberal moderado mineiro e marcando o panorama cultural da província: O Universal é o que refletirá, durante 17 anos, de 1825 a 1842, o pensamento filosófico, político e o ambiente filosófico mineiro." Um dos seus principais redatores foi Bernardo Pereira de Vasconcelos. SILVA, Wlamir. Liberais e o povo. A construção da hegemonia liberal-moderada na província de Minas Gerais (1830-1834). São Paulo: Hucitec, 2009. p. 130

2 AEGM: Arquivo 2; gaveta 2; pasta 2.

3 TRINDADE, Raimundo. Breve Notícia dos Seminários de Mariana. Mariana: Editada sob os auspícios da Arquidiocese de Mariana, 1951. 
selho Geral da província de Minas Gerais. ${ }^{4}$ A partir de 1829, Bhering passou a ocupar de maneira recorrente cargos políticos e administrativos, ${ }^{5}$ se inseriu nos crescentes "espaços públicos de sociabilidade" (foi redator de jornais, membro de sociedades e mantenedor de espaços de leitura), sem, com isso, abandonar a profissão de professor. ${ }^{7}$ Estevão Luz considerou que a demissão do Seminário "contribuiu para forjar sua projeção pública, marcando a sua ação política. Foi neste momento que deu início à sua carreira como escritor público e redator em periódicos mineiros, demonstrando ser um promissor ativista do pensamento liberal." ${ }^{\text {O }}$ Os espaços de fala conquistados e as redes de

4 Nas passagens em que utilizamos a designação "conselho provincial" referimo-nos ao Conselho Geral da Província (as atribuições desta instância serão especificadas em momento oportuno), e não aos Conselhos de Governo ou da Presidência, que eram "órgãos eletivos vinculados diretamente aos Presidentes de província, criados por decreto de 20 de outubro de 1823." Para uma análise aprofundada do tema ver: FERNANDES, Renata Silva. O governo das províncias do Império do Brasil: os Conselhos de Governo e os Conselhos Gerais de província nos debates parlamentares (1823-1834). Dissertação (Mestrado em História). Instituto de Ciências Humanas, Universidade Federal de Juiz de Fora, Juiz de Fora, 2014.

5 Transitou entre o âmbito local, provincial e nacional ao longo de sua vida. Foi vereador da Câmara de Mariana por três mandatos (1833-36, 1841-44 e 1852-55), membro do Conselho Geral (1830-32) e da Assembleia Legislativa (1835-37, 1846-49 e 1853-?) da província de Minas Gerais e deputado na terceira legislatura do Império (1834-37). Além disso, foi também Juiz de Paz de Mariana (1833-36 e 1840-?), Vice-diretor da Instrução Pública (1848) e Secretário da Província de Minas (1854-56).

6 Remetemo-nos a espaços públicos enquanto: "cena ou esfera pública, onde interagem diferentes atores, e que não se confunde com Estado; a esfera literária e cultural, que não é isolada do restante da sociedade e resulta na expressão letrada ou oral de agentes históricos diversificados; e os espaços físicos e locais onde se configuram estas cenas públicas.” MOREL, Marco. As transformações dos Espaços Públicos. Imprensa, atores Políticos e Sociabilidade na Cidade Imperial. São Paulo: Hucitec, 2003.

7 No mesmo mês de seu afastamento do Seminário, foi nomeado mestre de Filosofia e Francês da capital da província. A rápida acolhida em Ouro Preto e o imediato alarde causado por sua expulsão na principal folha de tendência liberal de Minas, nos leva a crer que Ribeiro Bhering já possuía alguma ligação com homens que o apoiariam na ofensiva movida contra Frei José.

8 LUZ, Estevão Marcondes. Incendiárias folhas: ação política e periodismo na trajetória do padre Antônio José Ribeiro Bhering (1829-1849). Tese (Doutorado em História). Faculdade de Ciências Humanas e Sociais, Unesp, Franca, 2016. p. 13. Ribeiro Bhering contribuiu com os seguintes jornais: O Novo Argos, O Homem Social, O Estrela Marianense, O Universal, O Parlamentar. Estevão Luz analisou sua atuação na imprensa periódica. 
relações estabelecidas foram utilizados por ele para investir contra o bispo de Mariana.

Dom Frei José da Santíssima era nascido em Portugal e transferiu-se para a Bahia em missão religiosa pela Ordem dos franciscanos. Assumiu o bispado de Mariana em 1820 e permaneceu a sua frente até 1835. Dentre todas as atividades possíveis, teve como uma de suas primeiras preocupações ao chegar em Minas a reabertura do Seminário de Nossa Senhora Boa Morte. A instituição de ensino foi fundada pelo primeiro bispo mineiro, Dom Frei Manuel da Cruz, em 1750. Segundo relato do viajante francês Auguste de Saint-Hilaire, a criação do Seminário esteve associada aos anseios de "alguns mineiros ricos que desejavam educar seus filhos, sem precisar enviá-los a Europa" e responsabilizou-o pela existência, "entre os proprietários de certa idade que habitavam os campos das comarcas de Sabará e Vila Rica” de "homens polidos e com certa instrução." No período que compreendeu entre os bispados de Frei Manuel da Cruz e Frei José, o Seminário enfrentou crises econômicas e administrativas, que levaram à suspensão total de suas atividades na década de $1810 .^{10}$

Dom Frei José esteve à frente da diocese mineira em um contexto de profundas transformações no Brasil, que estiveram atreladas reestruturação política, social e cultural iniciadas após a Independência. Segundo o cônego Raimundo Trindade, o conflito gerado em torno do Seminário de Mariana, que se iniciou com a expulsão de Ribeiro Bhering do quadro de professores, esteve entre os maiores desafios que

9 SAINT-HILAIRE. Apud VILLALTA, Luiz Carlos. Educação: nascimento, haveres e gênero. In: RESENDE, Maria Efigênia Lage de; VILLALTA, Luiz Carlos (orgs.). História das Minas Setecentistas. Belo Horizonte: Autêntica, 2007. p. 259

${ }^{10}$ Durante o bispado de Dom Frei Cipriano, antecessor de Dom Frei José, o Seminário teve um funcionamento bastante irregular. Logo quando chegou a Mariana lançou um edital convocando os jovens para estudar na instituição, mas logo abandonou a empreitada. Segundo Luiz Ferreira Carrato, o prelado manteve o costume de conceder ordenações sem a necessária passagem pelo Seminário. Oferecia, em contrapartida, aulas no próprio palácio episcopal, frequentadas por aspirantes ao sacerdócio ou não. CARRATO, Luiz Ferreira. Igreja, Iluminismo e Escolas Mineiras Coloniais. São Paulo: Cia. Editora Nacional/Edusp, 1968. 
o prelado teve que enfrentar. O local era um dos poucos estabelecimentos de ensino de Minas Gerais responsáveis por formar padres e oferecer ensino secundário aos jovens que seguiriam carreira em outras áreas. Na primeira metade do século XIX, instituições como esta extrapolavam a função religiosa e se projetavam como locais de ensino frequentados pelos filhos das elites desejosos de prosseguirem os estudos nos cursos superiores do Império ou até mesmo na Europa. ${ }^{11}$

Por esses motivos tanto Antonio José Ribeiro Bhering como Dom Frei José reconheciam a importância no Seminário, o vislumbrando como um espaço estratégico para formação da mocidade. Contudo, divergiam a respeito da instância que devia estabelecer os Estatutos de regência e o quadro de professores e sobre os conteúdos a serem ensinados. As discordâncias não se resumiam a um debate local, mas estavam associadas a impasses mais amplos surgidos nas décadas iniciais do processo de construção do Estado e da nação brasileiros.

\section{Fronteiras tênues: poder político e religiosos no Brasil Independente}

O restabelecimento das fronteiras entre os poderes políticos e religiosos esteve relacionado ao novo contexto político vivido no Brasil após a emancipação política. O regime monárquico constitucional apresentava-se como caminho escolhido pela maioria dos homens en-

${ }^{11}$ Não relacionamos o conceito de elite somente ao poder econômico, mas o atribuímos aos homens que desfrutavam, por motivos variados, de prestígio político, social e simbólico, capaz de dar-lhes visibilidade e distinção nos espaços que habitavam e de garantir-lhes o "direito" do exercício do poder. No que concerne aos estudos recentes sobre as elites, as considerações de Manuel Hespanha são relevantes para este trabalho. Para o estudioso português: "A história das elites (...) procura fixar rostos individuais. Identificar indivíduos antes de lugares institucionais, ou antes, de posição de classe. Olhar para poderes efetivos, antes de olhar para o direito ou para o "sistema social."” HESPANHA, António Manuel. Governo, elites e competência social: sugestões para um entendimento renovado da história das elites. In: BICALHO, Maria Fernanda; FERLINI, Vera Lucia (orgs). Modos de Governar: ideias e práticas políticas no Império Português (séculos XVI a XIX). São Paulo: Alameda, 2005. p. 40. 


\section{volvidos na experiência de autonomização do Brasil. ${ }^{12}$ A Constituição outorgada em 1824 representava essa opção. Nela, a religião católica foi definida como oficial do Império e tomada como um dos pilares de sustentação identitária e de conformação moral da nação. O regime do padroado foi, igualmente, mantido. ${ }^{13}$ Contudo, o grau de autonomia que os religiosos e seus espaços institucionais gozariam em relação aos}

${ }^{12}$ Nesse contexto, foram colocados em disputa projetos que apresentavam distintas possibilidades para a construção do Estado, de sua estrutura burocrática e de poderes, e da nação a ser forjada a partir de laços suficientemente fortes para manter unidas "as peças do mosaico" que viriam formar o território brasileiro. Posto desse modo, o ano de 1822 deixa de ser vislumbrado enquanto marco fundamental do nascimento do Estado e da nação brasileiros. Em contrapartida, as constituições desses aparatos são apreendidas enquanto experiências que se desenrolaram durante o século XIX e que contaram com projetos das elites políticas espalhadas nas localidades e de outros setores sociais, os quais experimentavam ao seu modo a nova situação. JANCSÓ, István; PIMENTA, João Paulo Garrido. Peças de um mosaico (ou apontamentos para o estudo da emergência da identidade nacional brasileira). In: MOTA, Carlos Guilherme (org.). Viagem incompleta. A experiência brasileira (1500-2000). Formação: histórias, 2. ed. São Paulo: SENAC, 2000. p. 127-175. Sobre o tema ver também as seguintes obras coletivas: JANCSÓ, István (org). Brasil: Formação do Estado e da Nação. São Paulo-Ijuí: Hucitec-Fapesp, 2003. CARVALHO, José Murilo; NEVES, Lúcia B. (orgs.). Repensando o Brasil do Oitocentos. Rio de Janeiro: Civilização Brasileira, 2009. CARVALHO, José Murilo. Nação e cidadania no Império: novos horizontes. Rio de Janeiro: Civilização Brasileira, 2007. GRINBERG, Keila; SALLES, Ricardo (org.). O Brasil Imperial Vol. I, II e III. Rio de Janeiro: Civilização Brasileira, 2009.

${ }^{13}$ Como esclarece Dalila Zanon: "O processo que redundou no padroado das conquistas ultramarinas e das dioceses novas do Reino pelos monarcas portugueses foi conseguido, grosso modo, no espaço de um século. Iniciada na metade do século XV, protagonizada pelo infante D. Henrique, e finalizada na metade do século XVI, no reino de D. João III. As sucessivas bulas papais desse período foram aos poucos concedendo ao Estado português dois padroados, ou seja, o padroado régio com a faculdade de fundar dioceses e escolher seus titulares e de administrá-las através da arrecadação dos dízimos, bem como, o direito do padroado dos benefícios menores, obtido através do Grão-Mestrado da Ordem de Cristo, com direito de fundar as igrejas nos territórios ultramarinos, escolher seus párocos, criar e nomear os canonicatos, capelanias e quaisquer outros benefícios eclesiásticos." O poder dos bispos na administração do ultramar português: o bispado de São Paulo entre 1771 e 1824. Tese (Doutorado em História). Instituto de Ciências Humanas e Sociais, Universidade Estadual de Campinas, 2014. p. 55 Em agosto de 1824, Dom Pedro I nomeou Monsenhor Francisco Corrêa Vidigal como seu representante em Roma para requerer o direito do exercício do padroado régio e do Grão-Mestrado da Ordem de Cristo. Depois de uma complexa negociação que demorou mais de dois anos, foram concedidas as demandas solicitadas. A resolução da questão foi postergada, pois ao conceder as atribuições a Dom Pedro I a Santa Sé estaria automaticamente reconhecendo a emancipação do Brasil. 
poderes públicos e como seriam estabelecidas as relações com a Santa Sé, onde estava instalado o centro unificador da Igreja católica, foram temas controversos. No mais, o Estado brasileiro começava a se inserir em campos, como o da educação, sobretudo através da elaboração de leis e garantias de direitos, historicamente controlados pela Igreja.

As questões concernentes a esse assunto eram complexas e provocavam clivagens no interior do próprio corpo eclesiástico. Não se resumiram, portanto, a um conflito dicotômico em que de um lado figurava o Estado nacional brasileiro e de outro a Igreja Católica Apostólica Romana e suas autoridades. É preciso estar atento para as abordagens historiográficas que apontam para ineficácia da atuação da Igreja e da implantação de "padrões tridentinos" em terras brasileiras. Nesses termos o padroado fora vislumbrado como usurpador da soberania papal. Como muito bem considera Dalila Zanon, o discurso historiográfico sobre a Igreja produzido em boa parte no século XX tendeu a "privilegiar o tema dos conflitos e a extinção do padroado na nascente república brasileira, em 1890." "14 Em relação ao período anterior prevaleceu a visão de uma Igreja que sofreu interferências constantes dos quadros políticos e administrativos, sendo o clero, sobretudo o secular, vislumbrado, quase de forma indiscriminada, como representante do poder régio.

Já no século XIX, a ideia de uma monarquia que se intrometia com frequência nos assuntos da Igreja começou a ser gestada. Ela serviu como uma das justificativas para implantação das reformas "ultramontanas", com as quais estiveram envolvidas autoridades romanas e bispos e padres brasileiros. ${ }^{15} \mathrm{O}$ movimento buscou conferir à Igreja "e especialmente ao clero, uma mentalidade romanista e universal,

${ }^{14}$ ZANON, Dalila. Op. Cit. p. 58

${ }^{15}$ Sobre as reformas ultramontanas ver: WERNET, Augustin. A Igreja Católica no século XIX. A Reforma de D. Antônio Joaquim de Melo (1851-1861). São Paulo: Editora Ática, 1987. AZZI, Riolando. O Altar Unido ao Trono. Um projeto conservador. São Paulo: Edições Paulinas, 1992. PEREIRA, Mabel Salgado. Romanização e Reforma Ultramontana: Igreja Católica em Juiz de Fora. Juiz de Fora: Irmãos Justinianos, 2004. 
afastada da problemática política nacional, e feita da estrita ortodoxia doutrinal, de rigorosíssimo ético e disciplinar, de sacramentalismo e devocionalismo interiorizado." ${ }^{16}$ No horizonte da reforma, encontrava o anseio de diminuir a interferência do poder público em assuntos religiosos, promover um alinhamento com a Santa Sé e corrigir os desvios no seio do clero. Uma das irregularidades que se julgava preponderar no Brasil consistia no envolvimento de padres com a política, com "escritos incendiários" e o suposto descaso diante de dogmas e aspectos disciplinares católicos. Riolando Azzi agregou relevância à atuação dos eclesiásticos responsáveis por assegurar a difusão desse ideário no Brasil. ${ }^{17}$ Ao designá-los como "bispos reformadores" ou "bispos religiosos", concedendo destaque à preocupação pastoral dos mesmos, o autor visou diferenciá-los dos prelados anteriores que, em sua percepção, se mantiveram mais ocupados com os assuntos seculares e administrativos das dioceses do que com as demandas espirituais dos fiéis. ${ }^{18}$

Se por um lado é incontestável o envolvimento dos padres com a vida política brasileira e com a defesa de projetos providos de controvérsias, por outro é preciso ter cautela com algumas abordagens generalizantes. Como alertou Magda Ricci, muitos dos padres envolvidos com questões políticas na primeira metade do século XIX tiveram suas atuações e projetos analisados de maneira desconectada com a suas motivações religiosas. No entanto, a condição de sacerdote e as identidades religiosas são elementos fundamentais para compreender

${ }^{16}$ SANCHIS, Pierre. "Os Brasis" da Igreja Brasileira. Revista Geraes, no . 46, 1987. p. 10

${ }^{17}$ Segundo o autor, seis bispos precisam ser lembrados quando estudada a reforma católica no século XIX: Dom Frei José da Santíssima Trindade (Mariana, 1820-35), Dom Viçoso (Mariana, 18441875), Dom Cláudio Gonçalves Ponde Léon (Goiás, 1881-1890), Dom José Afonso de Moreira Torres (Pará, 1844-1858), Dom Francisco de Cardoso Aires (Pernambuco, 1868-1870), Dom Vital Maria de Oliveira (Pernambuco, 1871 1878). AZZI, Riolando. Os bispos religiosos durante a época imperial no Brasil. Revista Convergências, ano IX, nº 92, maio de 1976.

${ }^{18}$ Riolando Azzi, juntamente com Eduardo Hoonaert, foi um dos mais destacados intelectuais católicos vinculados CEHILA, movimento intelectual católico alinhado a teologia da libertação. Segundo Zanon, o grupo, em grande medida, buscou no período colonial e imperial uma independência que não existia entre o poder religioso e político, o que o fez retomar a ideia da ineficácia da ação da Igreja enquanto instituição no Brasil antes da segunda metade do Oitocentos. 
as discussões em que eles se envolveram, bem como a projeção política do grupo e suas fissuras. ${ }^{19}$ Ao afirmar que muitos padres foram contemplados em trabalhos historiográficos, "todavia, o foram como fazendeiros, burocratas, representantes das elites provinciais, membros das camadas médias emergentes, jornalistas e construtores da opinião pública, estadistas, mas, raramente, como sacerdotes," ${ }^{20}$ Françoise Jean de Souza corrobora com tal colocação.

Os eclesiásticos estiveram na primeira metade do século XIX entre os segmentos que mais ocuparam cadeiras no Parlamento, ajudando a conformar a elite política do período. Mesmo que esta instância não tenha sido o lócus exclusivo de expressão das divergências entre padres, é interessante considerar as posições assumidas por eles na Câmara dos deputados e no Senado, pois tais espaços constituíram-se, sobretudo depois de 1826, como canalizadores dos mais urgentes "problemas nacionais". Além disso, foi a intensa a atividade do poder Legislativo nesse peculiar contexto que permitiu muitas das intervenções do poder público em espaços e assuntos religiosos ou ao menos tentativas nesse sentido.

A alta capacidade eletiva dos padres (nota-se que suas atividades não tiveram restritas ao âmbito local e provincial, sendo significativo o número dos que atuaram na Corte) esteve associada a uma cultura política marcadamente religiosa. ${ }^{21}$ Por um período considerável eles se mantiveram entre os poucos indivíduos letrados e foram os princi-

${ }^{19}$ RICGI, Magda Maria de Oliveira. Assombrações de um padre regente: Diogo Antônio Feijó (1784-1843). Campinas: Editora da UNICAMP, 2002.

${ }^{20}$ SOUZA, Françoise Jean de Oliveira. Do Altar à Tribuna. Os Padres Políticos na Formação do Estado Nacional Brasileiro (1823-1841). Tese (Doutorado em História). Gentro de Ciências Humanas e Sociais, Universidade Estadual do Rio de Janeiro, Rio de Janeiros, 2010. p. 21

${ }^{21}$ Para definição de cultura(s) política(s) as considerações de Serge Berstein são importantes: "Os historiadores entendem por cultura política um grupo de representações, portadoras de normas e valores, que constituem a identidade das grandes famílias políticas e que vão muito além da noção reducionista de partido político. Pode-se concebê-la como uma visão global do mundo e de sua evolução, do lugar que aí ocupa o homem e, também, da própria natureza dos problemas relativos ao poder, visão que é partilhada por um grupo importante da sociedade num dado país e num dado momento de sua história. BERSTEIN, Serge. A Cultura Política. In: RIOUX, Jean-Pierre; SIRINELLI, Jean-François. Para uma História Cultural. São Paulo: Estampa, 1998. p. 31 
pais difusores da cultura escrita. Em Minas Gerais, Luiz Carlos Villalta constatou que, entre fins do século XVIII e início do XIX, estavam entre os que mais possuíam livros. ${ }^{22}$ Também conciliaram as atribuições sacerdotais com outras atividades, como a agricultura, o comércio, o ensino e a imprensa. Isso os ajudava a complementar seu ordenado - e em muitos casos, torná-los elegíveis, uma vez que para ocupar cargos no legislativo era exigida uma renda mínima - e contribuía para reforçar a influência desses homens nas localidades onde viviam. Além disso, não abriram mão de recorrer a honrarias e títulos de prestígio, o que também lhes dava visibilidade. Cerca de $80 \%$ dos padres parlamentares foram agraciados com condecorações, como a da Ordem de Cristo. Do mesmo modo, alcançar ascensão na hierarquia da Igreja foi algo que eles não dispensaram; especialmente os que chegaram a compor o Senado, dificilmente consistiam em simples párocos, mas eram (ou viriam a ser) bispos, cônegos, etc.

Os projetos trazidos à tona na Câmara dos deputados e no Senado foram capazes de conformar alianças, mesmo que estas tenham sido marcadas por pulverizações. Isso não quer dizer que os padres parlamentares se arranjaram, entre as décadas de 1820 e 30, em organizações partidárias, portadoras de estatutos ou de lideranças pré -estabelecidas, embora alguns indivíduos tenham se destacaram pela veemência ao expor suas proposições, ou pela assiduidade com que ocupavam tais cargos. Nas discussões sobre a readequação das relações entre poder político e religioso, os padres dividiram-se, grosso modo, em duas tendências. Entre os temas mais polêmicos destacavam-se: os limites de atuação do legislativo em assuntos religiosos, como seriam estabelecidas as relações com a Santa Sé, seus ditames e autoridades, incluindo o Papa, e qual medida seria tomada diante da atuação das Ordens regulares no Brasil.

${ }^{22}$ VILLALTA, Luiz Carlos. A "Torpeza Diversificada dos Vícios": Celibato, Concubinato e Casamento no Mundo dos Letrados de Minas Gerais (1748-1801). Dissertação (Mestrado em História Social). Faculdade de Filosofia, Letras e Ciências Humanas, Universidade de São Paulo, São Paulo, 1993. 
Em um dos grupos reuniram-se a maioria dos eclesiásticos que compunham a Câmara dos deputados, entre eles: Diogo Feijó, Manoel Joaquim do Amaral Gurgel, José Bento Leite Ferreira de Melo, José Custódio Dias, José Martiniano de Alencar, Antônio Maria de Moura, José Miguel Reinaut, Francisco José Correia de Albuquerque e o próprio Antonio José Ribeiro Bhering. De maneira geral, eles defendiam que os campos em que a Igreja católica atuava e as instituições mantidas sob sua tutela deveriam ser organizados a partir das demandas da nação, a gozar, em algumas situações, de autonomia em relação aos ditames da Santa Sé.

Como pano de fundo dessa percepção encontrava um aspecto que merece ser destacado: a ideia de que a Independência do Brasil passava não só pelo fim do julgo de Portugal, mas de qualquer outro poder externo que pudesse interferir na soberania nacional. Tais eclesiásticos comungavam, assim, da ideia de que a religião católica deveria reestruturar-se diante das novas circunstâncias vividas e, para tanto, seria necessária a realização de reformas. O que tornava peculiar suas proposições não consistia propriamente no ideal reformista, uma vez que tal anseio, embora com projetos distintos, era compartilhado por outros setores religiosos. Ganhava destaque o caminho sugerido para realização das mudanças, tendo em vista que consideravam que a reforma eclesiástica - a qual adequaria a vivência religiosa e seus espaços institucionais "aos nossos usos e costumes" - deveria ser discutida e realizada via poder Legislativo.

Esse argumento serviu de base para sustentar a controversa ideia de que assuntos relacionados à disciplina eclesiástica poderiam ser modificados a partir das experiências locais. A proposta para o fim do celibato clerical debatida na Câmara dos deputados em 1827 foi uma das que ficou mais conhecida, gerando grande impacto junto a Santa Sé. ${ }^{23}$

${ }^{23}$ DORNAS FILHO, João. O Padroado e a Igreja Brasileira. São Paulo: Nacional, 1938. p. 56. Sobre a temática ver também: LUSTOSA, Oscar de Figueiredo. Reformismo da Igreja no Brasil Império: do Celibato à Caixa Eclesiástica. São Paulo: Loyola, 1985. WERNET, Augustin. A Igreja Paulista no Século XIX. São Paulo: Ática, 1987. 
Diogo Feijó foi o principal defensor do fim da exigência entre os padres brasileiros e teve apoio de outros religiosos, como Amaral Gurgel e Antônio Maria de Moura, sujeito que em 1833 foi nomeado bispo do Rio de Janeiro, tendo a indicação recusada pelo papa Gregório XVI. Como afirmou Françoise de Souza, esses religiosos "entendiam que o Estado, ao mudar alguns pontos da disciplina da Igreja, não estaria quebrando a unidade da fé, mas, tão somente, retomando o domínio sobre assuntos temporais que foram invadidos pela Igreja e que afetavam diretamente a sociedade brasileira." ${ }^{24}$

Outra questão que unia o grupo consistia na oposição à atuação das Ordens religiosas no Brasil. Os padres regulares, como eram designados, não dependiam das côngruas pagas pela monarquia, acumulavam bens materiais (sobretudo a partir de heranças) e obedeciam às regras das congregações que conformavam muitas delas estrangeiras. ${ }^{25}$ Para Sandra Molina, "era imprescindível à nação que se fortalecia afastar qualquer possibilidade de construção de um Estado paralelo e autônomo que se ligasse a lideranças estrangeiras." ${ }^{26}$ Feijó afirmava que deveria ser recomendado aos bispos que não instituíssem regulares estrangeiros para cargos eclesiásticos, uma vez que estes eram equiparados a um "emprego público". Além disso, considerava que qualquer autoridade brasileira, incluindo os bispos e o arcebispo, não poderia dirigir-se ao Papa sem antes pedir permissão ao governo brasileiro.

24 SOUZA, Françoise. Op. Cit. p. 330

25 "O clero secular deveria cuidar do cotidiano de sua vida terrena para assegurar o futuro de sua alma; enfim, tratar do saeculum. O clero regular, por sua vez, surgiu da necessidade de valorização da espiritualidade: era formado por monges residentes em mosteiros e conventos, cujas vidas regidas por diretrizes bastante específicas que definiam votos como caridade, castidade, silêncio, obediência e, em muitos casos, pobreza. Por pautarem-se em uma vida mais voltada à espiritualidade e à contemplação, desenvolveram um cuidado maior na preparação intelectual de seus frades e na preservação da cultura ocidental.” MOLINA, Sandra Rita, Des (Obediência), Barganha e Confronto: A Luta da Província Carmelita Fluminense pela Sobrevivência (1780-1836). Dissertação (Mestrado em História). Instituto de Filosofia e Ciências Humanas, Universidade Estadual de Campinas, Campinas, 1998. p. 7

${ }^{26}$ Idem, pp. 214-215 
No outro grupo de padres parlamentares tiveram atuação destacada o arcebispo da Bahia, Dom Romualdo Seixas e o bispo do Maranhão, Marcos Antonio de Souza. Esses homens também consideravam necessária a realização de reformas na estrutura da Igreja e, especialmente, na maneira pela qual se comportava o clero brasileiro. Contudo, não chegaram a encaminhar propostas reformistas para a Assembleia Legislativa, o que esteve associado ao fato deles não considerarem que era este poder o responsável por estabelecer as linhas mestras que promoveriam transformações no segmento e nas instituições eclesiásticos. ${ }^{27}$ Ainda que o grupo fosse numericamente reduzido, conseguiu consolidar uma forte oposição ao projeto reformista de Feijó e seus apoiadores. Não se pode perder de vista que contava com o respaldo da principal autoridade religiosa do país, o arcebispo da Bahia.

O grupo saiu em defesa de um maior alinhamento com as diretrizes de Roma e uma adequação da Igreja seguindo orientações do Concílio de Trento. Além disso, advogava a favor da manutenção da "tradição" católica e criticava as transformações causadas pelos processos que designavam "revolucionários". Romualdo Seixas, o grande defensor das prerrogativas romanas na Câmara dos deputados e no Senado, dizia que o Papa era quem possuía o direito soberano sobre a Igreja católica e sobre os eclesiásticos que a formavam. Ressaltava que mesmo o direito do padroado do qual desfrutava o monarca brasileiro só existia devido uma concessão da Santa Sé.

Um dos pontos de luta de Romualdo Seixas era a defesa de uma reforma cultural, espiritual e moral do clero no Brasil. Ele ansiava por uma readequação dos Seminários, pois em sua visão apenas a educação formaria sacerdotes mais conscientes de seus deveres. As cartas pastorais e sermões de Seixas "estiveram sempre repletos de referências ao papel fundamental desempenhado pelos Seminários como locais de "adestramento" cuja formação rígida favoreceria o surgimento de padres mais capazes de adequar-se à disciplina eclesiástica." ${ }^{\prime 28} \mathrm{O}$ clero

${ }^{27}$ Esta argumentação pode ser encontrada ao longo da tese de Françoise Jean de Souza.

${ }^{28}$ SOUZA, Françoise. Op. Cit. p. 400 
secular deveria, assim como a Igreja no Brasil, tornar-se cada vez mais independente do Estado e aproximar-se o quanto pudesse da ortodoxia de Roma. ${ }^{29}$ Nesse sentido, as proposições reformistas voltadas à Igreja ocorreriam seguindo as orientações romanas, e não as nacionais.

De maneira oposta ao segmento apontado anteriormente, esse grupo defendia a atuação do clero regular no Brasil, justamente por serem eles menos envolvidos com a política nacional e por respeitarem autoridades religiosas externas. Sustentavam a importância dos clérigos pertencentes a Ordens, especialmente no que concernia ao auxílio prestado para o cumprimento dos sacramentos, a atividade educativa e a catequização dos índios. Opunham-se também a alienação de seus bens materiais e alegavam que as corporações eram proprietárias particulares e desfrutavam do direito a propriedade como qualquer outro indivíduo. Dom Romualdo Seixas declarava ser um equívoco considerar todos os religiosos pertencentes a Ordens como jesuítas e indagava: "só porque eles têm hábitos são jesuítas? Isso é uma conjectura sem fundamento algum, porque poderá haver inimigos da nação vestidos de outro modo." 30

A defesa das Ordens religiosas pelo arcebispo da Bahia e pelo bispo da Maranhão associava-se ao início das reformas "ultramontanas" intensificadas na década de 1840. Os bispos engajados no movimento posto em prática em parceria com Roma depositaram justamente nas Ordens o encargo de aperfeiçoar a conduta do clero, sendo neste contexto vários Seminários episcopais entregues à administração de regulares. Foi ainda pelas ações empreendidas pelo clero regular que as ideias propugnadoras do fortalecimento de uma Igreja Universal e o alinhamento com as diretrizes do Sumo Pontífice se difundiram no território nacional. É interessante considerar que se nas décadas de 1820 e 1830 o grupo representado por Romualdo Seixas e Marcos Antonio de Souza não possuía muitos adeptos, isso se alteraria substancialmente no limiar do período Imperial. Para a pesquisadora Françoise Sou-

${ }^{29}$ MOLINA, Sandra Rita. Op. Cit. p. 188

${ }^{30}$ SEIXAS, Romualdo. Apud SOUZA, Françoise. Op. Cit. p. 344 
za, "o Brasil, que entrou no século XIX com utópicos projetos de ver emergir em suas terras uma Igreja abrasileirada, presenciou, no ocaso do Oitocentos, a formação de uma Igreja romanizada."31

Abordar as questões que dividiam os eclesiásticos no Parlamento consiste em importante exercício para apreensão dos dilemas enfrentados no processo de readequação das relações entre poder político e religioso após a Independência do Brasil. Entretanto, a política formal da Corte não foi o único espaço que os eclesiásticos atuaram, nem local exclusivo de debates e discordâncias. Inserimos o conflito analisado por nós, desenrolado em torno do Seminário de Mariana entre 1829 e 1835, especialmente no que referia à definição de seus Estatutos e do quadro de professores, em meio aos dilemas surgidos nesse contexto. Era vislumbrada a necessidade de reconfiguração dos poderes numa nova lógica de governança, mas não havia unanimidade acerca ao caminho a ser trilhado.

\section{O bispo Dom Frei José e a soberania do poder religioso no Seminário de Mariana}

Os esforços empreendidos por Dom Frei José da Santíssima Trindade para reabertura do Seminário de Mariana, viabilizada apenas cinco meses após ter se instalado em Minas Gerais, demonstrava a importante função atribuída pelo prelado à instituição de ensino, algo que viria a ser confirmado nos anos subsequentes do seu governo eclesiástico. $\mathrm{Na}$ ocasião, o bispo reformulou os Estatutos do colégio episcopal, substituindo os em vigor desde $1760 .{ }^{32}$ No documento Frei

\footnotetext{
31 Idem, p. 406.

32 Os Estatutos contemplavam as regras de regência do Seminário. Nele estavam inclusas as disciplinas oferecidas na instituição, as diretrizes comportamentais que deveriam ser seguidas pelos alunos e mestres e definições de ordem econômica e administrativa. Para uma análise mais detalhada das regras de regência do Seminário de Mariana reformuladas por D. Frei José ver: ALMEIDA, Gabriela. Jogos de Poderes: o Seminário de Mariana como espaço de disputas políticas, religiosas e educacionais (1821-1835). Dissertação (Mestrado em História) Instituto de Filosofia e Ciências Humanas, Universidade Estadual de Campinas, Campinas, 2015.
} 
José expôs de forma clara que o governo do Seminário era privativo dos bispos e expressou que caberia a esta autoridade nomear o reitor, definir o quadro de professores, indicar o administrador das rendas, elencar quais conteúdos seriam ensinados e como os indivíduos que o frequentavam deveriam se portar. O que ele não pôde prever era que a elaboração de novos Estatutos lhe renderia grandes infortúnios.

Com a exoneração de Antonio José Ribeiro Bhering do quadro de professores, Frei José passou a ser duramente criticado pelo mesmo. O padre e professor de Filosofia conquistou apoios e utilizou espaços de fala, como a imprensa e o Conselho provincial para manifestar o descontentamento diante de sua demissão, e da maneira pela qual o bispo organizava e administrava o estabelecimento de ensino. Bhering declarava que a reforma empreendida nos Estatutos era inconstitucional, uma vez que o bispo não solicitou permissão à Assembleia legislativa para realizá-la. Diante de tal colocação, tanto o órgão supremo do legislativo nacional, quanto o Conselho provincial de Minas solicitaram esclarecimentos de Frei José acerca da questão.

Vale recuperar, ainda que de maneira breve, o histórico de formação e as atribuições do Conselho Geral da Província, um dos espaços onde o conflito entre os dois eclesiásticos reverberou. A delimitação política e administrativa das províncias teve início no Brasil a partir da década de 1820, estando diretamente relacionada à demarcação dos espaços políticos constitucionais. De acordo com Iara Lis Schiavinatto, "esta dinâmica de reordenação da rede de poder propiciava uma maleabilidade no mando local e na centralização do poder." ${ }^{33}$ Ao Conselho Geral da Província, órgão eletivo com criação prevista na Constituição de 1824, foram reservadas as funções de "propor, discutir e deliberar sobre os negócios mais interessantes de suas províncias, formando projetos peculiares e acomodados as suas localidades e urgências, discutindo 'a portas abertas' os negócios que começarem nas

${ }^{33}$ SCHIAVINATTO, Iara Lis Franco. Pátria Coroada. O Brasil como corpo político autônomo, 1780-1831. São Paulo: Editora Unesp, 1999. p. 116 
Câmaras." ${ }^{34}$ Suas resoluções deveriam ser enviadas ao poder Executivo que as encaminhava, passando antes pela Secretaria do Estado, à Assembleia Geral Legislativa. Deste modo, os conselhos provinciais elaboravam projetos, mas não tinha autonomia legislativa. Esta autonomia foi conquistada em 1834, com o ato adicional que criou as Assembleias Legislativas provinciais. ${ }^{35}$

Apesar de ter sido criado em 1824, o Conselho provincial de Minas Gerais começou efetivamente a funcionar quatro anos depois, uma vez que na Constituição do Império definiu-se que o seu regimento seria elaborado pela Assembleia Geral. Isso foi concretizado em 1828, tendo em vista que após a dissolução da constituinte, somente em 1826 o órgão supremo do legislativo retomou suas atividades. A partir deste ano estiveram entre os temas mais tratados pelo Conselho as questões financeiras ("das rendas públicas”); as vinculadas à prosperidade econômica, aqui aparecem debates especialmente sobre a agricultura e o comércio; as demandas relacionadas ao escoamento da produção, destacando a necessidade de melhoramento das estradas, construção de pontes, contratações de profissionais que atuariam nessas melhorias, como engenheiros; e sobre a instrução pública, propunha-se a criação de aulas, que abrangiam conteúdos variados e reformas nos estabelecimentos de ensino já existentes na província. Além disso, inseriam-se entre as discussões dos conselheiros, questões relacionadas à administração e justiça, sobretudo as concernentes as posturas das Câmaras municipais.

${ }^{34}$ Idem, p. 52

${ }^{35}$ Maria de Fátima Gouvêa salientou "o papel central das províncias na formação da monarquia constitucional brasileira, na medida em que instituições como as assembleias provinciais serviam como espaço essencial para a consideração e acomodação da extraordinária diversidade de interesses que pululavam nos espaços provinciais. Não apenas isso, mas também deputados provinciais capazes de inter-relacionar os vários grupos políticos, econômicos e sócias em apoio à definição e a implementação de uma programa de exportação baseado na mão de obra escrava." GOUVÊA, Maria de Fátima S. O Império das províncias. Rio de Janeiro, 1822-1889. Rio de Janeiro: Civilização Brasileira/FAPERJ, 2008. p. 10. 
Em 1821, quando o bispo de Mariana tornou públicas as novas regras de regência do Seminário, o poder legislativo brasileiro ainda não havia se organizado. Entretanto, Ribeiro Bhering considerava que a partir do momento em que a nação passou a ser regida por uma Constituição, tudo que dizia respeito à "vida pública" deveria ser definido nos limites das leis. Se necessário fosse, posturas tomadas antes da Independência ou durante o processo de autonomização deveriam ser revistas. Dom Frei José, por sua vez, não se rendeu facilmente às cobranças e também buscou estabelecer apoios para manter viva sua autoridade diante da instituição. Seu esforço não foi em vão, uma vez que até a sua morte ao menos os Estatutos que elaborara foram mantidos no Colégio episcopal. Além disso, sua postura foi elogiada por autoridades romanas, como trataremos adiante.

O primeiro escrito no qual Frei José se pronunciou de forma categórica acerca do conflito estabelecido com Antonio José Ribeiro e da oposição que vinha sofrendo nos assuntos do Seminário datou de dezembro de 1830, e foi destinado ao Núncio Apostólico, Monsenhor Pietro Ostini. Era esta uma autoridade eclesiástica que tinha como função mediar conflitos e tomar decisões que envolviam a religião católica em territórios distantes de Roma, servindo como um representante do Papa na localidade. Após a Independência, o primeiro Núncio se instalou no Brasil no mesmo ano em que Frei José lhe escrevera. A estadia de Monsenhor Ostini em território brasileiro esteve longe de ser tranquila, ele sofreu constante oposição de políticos e redatores de jornais que não consideravam legítima sua atuação. ${ }^{36}$ Para o grupo que lutava contra à nunciatura, o monarca era quem deveria intervir nas questões religiosas manifestas em limite nacional, em vista que gozava do direito do padroado. Havia, portanto, o esforço de "monitorar a atuação da nunciatura no sentido de evitar que ela conferisse aos bispos atribuições que não lhes pertenciam, bem como de evitar que

${ }^{36}$ HAUCK, João Fagundes; et all. História da Igreja no Brasil: Ensaio de interpretação a partir do povo - Segunda Época: A Igreja no Brasil do século XIX. $3^{\text {a }}$ edição. Petrópolis: Edições Paulinas/ Vozes, 1992. pp. 79-80. 
ela fomentasse uma campanha em prol das ideias ultramontanas que feriam a autonomia do poder temporal." ${ }^{\prime 37}$ De forma distinta, Dom Frei José parecia reconhecer a autoridade e as atribuições do Núncio Apostólico, uma vez que recorreu a ele para denunciar a oposição que vinha sofrendo.

Um Núncio Apostólico já havia se instalado na América portuguesa antes de 1830. Tratava-se de Monsenhor Lorenzo Caleppi, que aportou no Rio de Janeiro em 1808 junto com a Corte portuguesa. Acompanhando Caleppi, deslocou-se também o secretário da nunciatura, Camilo Luigi de Rossi, que permaneceu na função até 1815, ano em que foi nomeado por Dom João VI, com a aprovação do Santo Padre, para o cargo de Cônsul Geral e Agente de Negócio da Corte portuguesa junto a Santa Sé. ${ }^{38}$ Dom Frei José se correspondeu em mais de uma ocasião com Camilo Rossi após 1822, momento em que, ao menos oficialmente, ele não possuía mais ligação com o Brasil. Somente no ano de 1829, o prelado escreveu quatro vezes ao Cônsul português. Nas correspondências buscava ressaltar a sua adesão ao Papa e às autoridades instituídas pela Santa Sé, e salientar sua repugnância em relação às proposições que feriam diretamente a ortodoxia católica.

Em uma das cartas o bispo expressou de maneira genérica as dificuldades enfrentadas: "atualmente vivo em grandes perturbações assim pelo Ministério Santo [...] pelas circunstancias destes calamitosos tempos." Já em outra, Frei José expôs de maneira clara quais eram os temas que o afligiam: "trabalha-se na Assembleia pela admissão da liberdade de consciência, na destruição do celibato clerical, na ruína das corporações religiosas e agora na secularização do matrimonio como contratos... E logo trabalharão em reduzir a religião a lei, como no tempo de Henrique 8 !" $40 \mathrm{O}$ bispo alegava que floresciam "escri-

\footnotetext{
${ }^{37}$ SOUZA, Françoise. Op. Cit. p. 341

${ }^{38}$ ACCIOLY, Hildebrando. Os Primeiros Núncios no Brasil. São Paulo: Instituto Progresso Editorial, 1949. p. 36

${ }^{39}$ AECM: Arquivo 2, gaveta 2, pasta 8.

${ }^{40}$ Idem.
} 
tos e discursos bem fundados em defesa da religião e das Santas Ordenações da Igreja, porém estas verdades claras são repudiadas pela liberdade impune de escrever." 41 Asseverava que as dificuldades eram enormes, pois os homens "probos" ao invés de terem seus escritos elogiados, eram taxados de "fanáticos".

Se o bispo de Mariana já escrevera para um Cônsul português atuante junto a Santa Sé a fim de expor os debates que julgava inconcebíveis, dificilmente deixaria de fazer o mesmo quando uma autoridade romana, o Núncio Apostólico, foi instituída na Corte carioca. Dom Frei José comunicou-o que na reunião do Conselho da província de Minas Gerais, em princípio de dezembro, "começaram já a tratar sobre o meu Seminário Episcopal, para chamar a si a revisão e exame dos Estatutos, que eu lhe dei na sua restauração, a título de inconstitucionalidade." ${ }^{2}$ Demonstrava indignação ao assegurar que o autor do questionamento era Antonio José Ribeiro Bhering, um sacerdote criado no Seminário, por ele sustentado e provido de livros por tempo de seis anos. O bispo dizia ter sido "constrangido" a lançá-lo fora e a partir de então ele "se desmascarou em escritos públicos contra mim, contra seus mestres e contra o próprio Seminário a quem deve sua prosperidade dirigindo a incendiária folha intitulada $\mathrm{O}$ Argos de Minas". ${ }^{43}$ Como se não fosse suficiente, juntou-se a "outros demagogos naquele Conselho, que parece disposto a desacreditar o Seminário e fazê-lo odioso, para apressar a sua destruição e abandono." ${ }^{\prime 4}$

Frei José expediu tal carta não somente como forma de relato, mas a fez principalmente para solicitar um conselho. $\mathrm{O}$ prelado consultava o Núncio Apostólico se deveria ou não conceder explicações ao Conselho da província acerca dos Estatutos reformulados. Ao mesmo tempo, Frei José não deixou de expor um breve histórico do Seminário de Mariana. Disse que encontrara o mesmo sem funcionamento e

\footnotetext{
41 Idem

42 Idem

43 Idem

44 Idem
} 
salientou seus esforços para reabri-lo. Como conclusão da carta fez notória sua submissão ao Núncio e ressaltou que a indicação da postura a ser tomada lhe era de grande valia. Infelizmente, não localizamos a resposta de Monsenhor Ostini, possivelmente seus escritos estão recolhidos em arquivo relacionado à nunciatura. De todo modo, Frei José continuou nos anos subsequentes sendo cobrado acerca dos Estatutos, o que leva a crer que ele recusava-se a entregar o documento ao Conselho provincial.

Em outra correspondência, dessa vez direcionada à Augusta e Apostólica Assembleia Legislativa, datada de 1831, Dom Frei José voltou a reclamar de maneira enfática acerca das intervenções feitas por parte do Conselho provincial em assuntos que, na sua concepção, diziam respeito somente ao bispado. No pronunciamento, ele deixou mais uma vez transparecer que considerava a administração do Seminário como uma incumbência da diocese. Como pode ser vislumbrada a seguir, a sua argumentação baseava-se no Concílio Trento e em bulas e decretos provenientes da Igreja, todos datados de antes da Independência.

Parece forçoso na sabedoria dos mesmos conselheiros, que o governo privativo do Bispo de Mariana entre nas suas discussões, e resoluções [...] Sempre lhe aqui foi respeitado o Decreto do Sagrado Concilio Tridentino na Sessão 23 cap. 18 para a criação, e conservação dos Seminários Episcopais, encarregando aos Bispos toda a sua administração, e governo, e os alvarás de 11 de outubro de 1786, o de 22 de março de 1796, e o de Maio de 1805 o aprovaram, e protegeram assim, e da mesma forma, que o mesmo Concílio, e outros muitos, e bulas Apostólicas ordenaram como defensores, e protetores dos cânones sagrados: mas o Conselho geral dessa Província solicita que o Seminário Episcopal de Mariana subscreva a novas fórmulas, bem como aconteceu com a pastoral de 28 de outubro. ${ }^{45}$

Frei José afirmou estar sendo muito pressionado pelo Conselho e, por isso, solicitava proteção da Assembleia Legislativa. Salientava que "o mesmo bispo ou [deveria] ser fiel aos seus juramentos na defesa e observância da disciplina e cânones da Igreja, ou obedecer às atas do

45 AECM: Arquivo 2; Gaveta 2; Pasta 14. 
Conselho e ser perjuro." ${ }^{46}$ O prelado concluía em tom de lamúria que "de outra sorte não pode viver o bispo entre tantos conflitos, e perturbações, que aumentam a desordem, e desconfiança entre o pastor e as ovelhas". ${ }^{47}$ Sugerimos que nesse momento Frei José recorreu à Assembleia Geral por considerar que o Conselho provincial estava excedendo o que lhe era concedido enquanto poder decisório. O órgão político superior a ele poderia ser, portanto, responsável por frear suas ações. Ademais, Frei José lembrava que não era esta a primeira ocasião que o Conselho da Província proferia ataques contra ele e se intrometia em assuntos religiosos. ${ }^{48}$

A percepção de Frei José acerca de como deveriam estar dispostas as fronteiras entre poder político e religioso ficou clara em uma carta pastoral escrita em 1832. No documento, o prelado buscou definir como deveria constituir-se o Beneplácito Nacional sobre as matérias eclesiásticas. De início esclareceu que o reino de Deus era todo espiritual, não sendo legítima a intromissão do poder temporal em assuntos religiosos. Afinal, como ele afirmava "Jesus Cristo fundou sua Igreja, legislou, e mandou os apóstolos a todas as nações, e nem por isso requereu licença de Cezar." ${ }^{49}$ Os governantes, por sua vez, acolheram a Igreja católica e os preceitos pelos quais ela estava organizada, sem ter o direito de intervir em matéria de fé, doutrina e disciplina. Para conservação desses preceitos universais foi instituído o Papa, "conce-

\footnotetext{
${ }^{46}$ Idem

${ }^{47}$ Idem

${ }^{48}$ Frei José se referia à oposição do Conselho da província a pastoral que emitiu em 28 de outubro de 1828. Nela ele se opôs ao decreto da Assembleia Legislativa, datada de 3 de novembro de 1827, que determinava não ser mais necessária a licença dos bispos para um matrimônio ocorrer nos limites diocesanos. Com isso, o pároco era quem passava a ser o responsável por averiguar se existiam impedimentos canônicos para realização do enlace. Era ainda estabelecida a proibição da cobrança de emolumentos para realização das cerimônias. Em sua pastoral o bispo de Mariana determinou que os párocos viventes nos limites de seu bispado continuassem respeitando os antigos preceitos que guiavam a realização dos casamentos, não permitido, portanto, a consumação dos mesmos sem o seu aval. A principal justificativa apresentada consistia no fato do matrimônio ser um dos sacramentos e, assim sendo, somente o poder religioso teria o direito de alterar a sua jurisdição.

49 AECM: Arquivo 2; Gaveta 2; Pasta 9.
} 
dendo-lhe não só a primazia de honra, mas também o poder e jurisdição sobre toda a Igreja Universal, como a Fé nos ensina, e cuja posse pacífica sempre gozarão os Romanos Pontífices, onde sempre residiu o sobredito poder." ${ }^{50}$ Nas localidades, esse poder se estendia aos pastores da primeira ordem, isto é, sobre aos senhores bispos. Não cabia aos monarcas qualquer possibilidade de interferência nas leis eclesiásticas, caso houvesse alguma intromissão o reino espiritual estaria ameaçado pelos caprichos e paixões dos chefes políticos.

Seguia dizendo que não foi sempre que os monarcas gozaram do direito de nomear os bispos para as dioceses. Para esclarecer tal afirmação, indagava: "A quem deve pertencer e prover o culto religioso, escolher e investir com as qualidades correspondentes ao sublime Ministério eclesiástico, Ministério de paz e conciliação entre o Deus vivo, senão a mesma Igreja?" 51 Pensando em perspectiva histórica, asseverava que o primeiro governante que "nessa parte invadiu os direitos da Igreja foi Constâncio filho de Constantino. (...) Depois deste muitos outros príncipes invadiram o direito da Igreja, mas a Igreja quanto pode, sempre reclamou." 52 Argumentava que, em situações específicas, os príncipes foram condecorados "com o privilégio do Acesso Real, e se estabeleceram concordatas entre os dois poderes para melhor harmonia" ${ }^{53}$, contudo, jamais foi atribuído ao poder político o direto de intervir em assuntos estritamente religiosos como, por exemplo, a organização interna das dioceses.

No que concerne especificamente às relações entre Estado brasileiro e Igreja católica, Frei José explicava que "se o Imperador do Brasil por si, e seus ministros entram no exercício de muitas matérias eclesiásticas, é pelo privilégio do padroado; mas nunca pôde subir fora ou passar além do que lhe foi concedido, sem a Santa Sé ser ouvida." ${ }^{54}$

\footnotetext{
50 Idem

51 Idem

52 Idem

53 Idem

${ }^{54}$ Idem
} 
A última colocação a esse respeito consistia nos efeitos gerados, caso o poder político avançasse a fronteira jurisdicional reservada aos setores eclesiásticos: "se o poder temporal pudesse intrometer-se nas leis já estabelecidas pela Igreja toda a harmonia religiosa se tornaria uma confusão; perigariam as consciências, desapareceria a paz, e a mesma sociedade deveria dilacerada aos golpes de perseguição." ${ }^{.5}$

Antes de findar a pastoral, Frei José teceu ainda consideração acerca de outro tema: o patrimônio material pertencente à Igreja. O prelado afiançava que a Igreja católica gozava do direito as suas propriedade. ${ }^{56}$ Isso "porque N. S. Jesus Cristo, redentor e fundador da sua Igreja, quando disse aos dirigentes que o seu Reino não era desse mundo, não lhes tirou a natureza de homens, e de viventes; nem lhes tirou o direito de viverem de seu trabalho." ${ }^{57}$ Além de desfrutar do direito de posse dos edifícios que lhes foram doados por sujeitos que recorriam ao socorro da Igreja, tinham também o direito de receber doações dos fiéis pelos serviços prestados e distribuir, mediante a intervenção dos bispos, entre os sacerdotes. Destarte, os "frutos oferecidos a Igreja são tanto temporalidades da Igreja e de sua propriedade como são direito da Nação as contribuições que pagam os povos a quem administra a justiça, conserva a paz, e defendem suas vidas e propriedades." 58

Diante do exposto, fica claro que Dom Frei José não aceitava as interferências do Estado nacional em construção nos assuntos que considerava ser de exclusivo controle da Igreja. Não sem motivos estabeleceu redes de contato em âmbito nacional e internacional com sujeitos que defendiam a maior autonomia do poder religioso e um alinhamento com a Santa Sé.

\footnotetext{
${ }^{55}$ Idem

${ }^{56}$ Frei José definia o que entendia como direito de propriedade: "Um dos direitos de propriedade é a faculdade que cada um tem de usar e dispor do que é seu". Idem

${ }^{57}$ Idem

${ }^{58}$ Idem
} 


\section{Um "padre político" na província mineira: Antonio José Ribeiro Bhering e os embates com Dom Frei José}

Antonio José Ribeiro Bhering inseria-se entre os defensores da intervenção do poder temporal em questões religiosas manifestas nos limites da nação. Como dito, ele esteve entre os conselheiros da província empenhados em "tirar o sossego" de Frei José e questionar a maneira pela qual o mesmo desenhava a linha definidora do que cabia ao poder público e ao religioso. O professor de filosofia defendia que os Estatutos de regência do Seminário deveriam ser aprovados pelo Conselho provincial e pela Assembleia Legislativa, tendo em vista que tratava-se de uma temática de interesse nacional. Em meio às atas das sessões do Conselho, ficou registrado que Bhering acusou o bispo de ser uma autoridade omissa, devido à demora para responder as questões que lhe eram postas:

O senhor Bhering disse que autoridades que se inculcavam de muitas exatas e virtuosas, e que incessantemente clamam contra a liberdade de nossos tempos, eram as mais omissas, em cumprir com os seus deveres, porque tendo pedido a mais de mês ao Exmo. bispo de Mariana a cópia dos Estatutos do Seminário daquela cidade, até agora não se tinha remetido, para tanto requerias que de novo se oficiasse instando pela remessa. ${ }^{59}$

Ribeiro Bhering ia além de solicitar as normas de regência formuladas por Frei José. Como também expôs nas sessões do Conselho, considerava que o Seminário necessitava "de uma nova administração e de ser regulado por novos Estatutos para assim preencher os fins de sua instituição e ser útil não só a mocidade que se dedica ao estado eclesiástico, como aos outros ramos da educação civil." ${ }^{60}$ Partindo dessa percepção, propôs que Mariana fosse transformada em um centro

\footnotetext{
${ }^{59}$ APM: Fundo Conselho Geral da Província, Notação CGP 3/1 Cx. 03

${ }^{60}$ APM: Fundo Conselho Geral da Província, Notação GGP-03
} 
de estudos preparatórios para o ingresso nos cursos superiores do Brasil, sobretudo na Academia Jurídica de São Paulo.

O projeto era justificado pela necessidade de congregar em um só lugar as cadeiras que se encontravam espalhadas por Minas Gerais. Para tanto, as matérias de Geometria e Filosofia, já providas em Ouro Preto, seriam transferidas para a sede do bispado, e seria criada uma disciplina de Língua francesa. Mariana era caracterizada como o local mais apropriado para congregação de todas as aulas, pois oferecia "as necessárias proporções e comodidade aos estudantes”, que houverem de concorrer de diversas partes da província, o que levava a transferir para aí as mencionadas cadeiras lembrando ao mesmo tempo "a vantagem que resultará de se darem todas as lições no Seminário.”ø1 A escolha da cidade não era aleatória, justificava-se pelo fato de ser centro religioso e onde estava instalada uma das principais instituições de educação de Minas Gerais. Ademais, é preciso dizer que segundo a proposta o Seminário não deixaria de ser um local destinado à formação de padres.

Em um momento posterior (1832), quando Ribeiro Bhering não mais compunha o Conselho, foi apresentada outra proposta para promover o progressivo melhoramento das três casas de educação que existiam na província: o Seminário de Mariana, o Colégio do Caraça e o Colégio de Matosinho de Congonhas, todos administrados por religiosos, o primeiro pela diocese e os dois últimos por Ordens regulares. Quem assinou o projeto foi Batista Caetano de Almeida ${ }^{62}$ e a justificativa apresentada consistia no fato dele estar "convencido de que a di-

${ }^{61}$ AECM: Arquivo 2, Gaveta 2; Pasta 2.

${ }^{62}$ Batista Caetano foi um comerciante da Vila de SãoJoão Del Rei, importante interposto comercial devido à proximidade com a Corte. $\mathrm{O}$ ofício de comerciante foi introduzido por um tio. Dedicou-se também a atividades políticas em âmbito local, provincial e nacional, e a editoração de jornais. Em vários números do jornal O Novo Argos, período em que Ribeiro Bhering também foi redator, foram feitas alusões e publicados excerto do Astro de Minas. Além das citações, um segundo elemento tornava explícito o compartilhamento de escritos e ideias entre estes sujeitos: a subscrição do Argos poderia ser feita na Tipografia do Astro, em São João, mediante o pagamento de 800 rs. por trimestre ou 80 rs. por folha avulsa. 
reção dada à educação nos mesmos não é conforme as luzes do século em que vivemos, nem tão bem é capaz de imprimir nos ternos corações da juventude mineira amor à pátria, e as instituições que felizmente nos regem." ${ }^{\prime 3} \mathrm{O}$ projeto foi descrito e elogiado no jornal $O$ Homem Social, no qual Ribeiro Bhering foi provavelmente o único redator. ${ }^{64}$

Batista Caetano afirmava que as instituições de ensino de Minas Gerais deveriam estar disponíveis para receber disciplinas criadas ou transferidas pelo Conselho provincial. Tal medida geraria melhorias, pois "as cadeiras disciplinares isoladas nenhum proveito tem dado a mocidade mineira, quando nos colégios e de baixo da direção de um plano regular e metódico de estudos, tal qual o Conselho apresenta em sua proposta, vantajoso resultado haverá a favor da instrução e da moral pública. ${ }^{\prime 65}$ Em outras palavras, as casas de educação demandavam nova organização, que deveria ser estabelecida pelo poder político.

No que concerne especificamente ao Seminário de Mariana, Batista Caetano destacou que preponderava na instituição uma desorganização em termos administrativos e financeiros. Segundo o projeto de reforma elaborado pelo Conselho, até a década de 1820 não existiam Estatutos que regulavam a instituição, "o atual prelado disse que eles se haviam perdido, pelo o que organizara outro em 1821, o que induz o Conselho a supor que por muito tempo as rendas do Seminário estiveram sujeitas ao árbitro dos reitores e procuradores." 66

A proposta era composta por doze artigos e contemplava os três estabelecimentos de ensino, todos, como dito, administrados por religiosos. Nela ficou definido que o Conselho provincial concederia auxílio financeiro às casas de educação, em troca seria admitido certo número de alunos pobres e acatadas as decisões tomadas na instância políti-

${ }^{63}$ APM: Fundo Conselho Geral da Província, Notação GGP-07.

${ }^{64}$ O HOMEM SOCIAL. Mariana: Tipografia Marianense $\mathrm{n}^{\circ}$ 47, 1832.

${ }^{65}$ APM: Fundo Conselho Geral da Província, Notação CGP-07.

${ }^{66}$ APM: Fundo Conselho Geral da Província, Notação CGP-07. Vale lembrar que o primeiro bispo de Mariana, Dom Frei Manuel da Cruz, elaborou os Estatutos de regência do Seminário no período de sua abertura. Em 1821, Frei José estabeleceu novas regras de regência por julgar as anteriores insuficientes. 
ca provincial. Os estudantes desprovidos de meios seriam indicados pelas Câmaras municipais e "além das demais matérias disciplinares se aplicar[iam] no $5^{\circ}$ ano nos estudos elementares de agricultura e noções gerais de zoologia e botânica" e, quando concluído este curso, seriam nomeados "lentes das cadeiras preparatórios dos seus respectivos municípios." As matérias disciplinares seriam reguladas por um plano de estudos aprovado pelo Conselho e ao presidente desse órgão seria reservado o direito de "transladar para cada um destes colégios qualquer das cadeiras disciplinares já criadas de ora em diante".

Os bens de raízes e móveis seriam inventariados por "autoridade territorial competente, a qual proceder[ia] em tudo na conformidade das leis." Os administradores dos colégios seriam obrigados a apresentar ao presidente da província relatórios circunscritos "acompanhado da receita e despesa." Referindo-se ao Seminário de Mariana, definiu-se que o bispo continuaria responsável pela formação de padres, "assim como pela nomeação dos lentes de Teologia moral e dogmática, procedendo contudo concurso na forma das leis." Por fim, se deliberou que o presidente do Conselho nomearia "todos os anos uma comissão para examinar os citados estabelecimentos, quer na parte administrativa, quer na científica, e literária, e nas vistas das informações obtidas apresentará ao Conselho as medidas, e reformas que os mesmo precisarem." ${ }^{97}$

Como pode ser vislumbrado, além de delimitar como seriam organizadas as instituições, caberia ao espaço de poder provincial investir recursos financeiros e dotar os estabelecimentos de um novo plano econômico, fiscalizar como estavam sendo desenvolvidos os trabalhos através de relatórios e de comissões encarregadas de visitar periodicamente os estabelecimentos, definir os planos disciplinares e instituir aulas e professores. Uma preocupação específica era demonstrada em relação aos alunos pobres, que passariam a ter um número de vagas reservadas. Esses jovens já tinham seu futuro definido: possivelmente não seguiriam para os estudos universitários, e sim servirem como pro-

${ }^{67}$ Todos os trechos citados neste parágrafo são provenientes do mesmo documento: APM: Fundo Conselho Geral da Província, Notação GGP-07. 
fessores em cursos preparatórios em seus municípios. O bispo diocesano não ficaria totalmente sem função, a ele caberia coordenar o ensino destinado aos jovens que ambicionavam se tornar padres e nomear os professores de Teologia. Mas, mesmo esta última atribuição deveria ocorrer em consonância com as leis, através da submissão dos candidatos a exames públicos.

Quando Antonio José Ribeiro Bhering ocupou cadeira na Câmara dos deputados, defendeu um projeto que dialogava com esse. Denunciando o abandono em que se encontrava o ensino no Brasil, propôs a criação de Seminários em todas as dioceses. Para tornar viável a proposta sugeriu que o "governo geral arcasse com os fundos necessários à construção destes Seminários, utilizando-se, para tanto, de quantas loterias fo[ssem] necessárias para a conclusão das obras." ${ }^{\prime 68} \mathrm{O}$ projeto demonstrava que Ribeiro Bhering não considerava a criação e a manutenção dos colégios episcopais como uma incumbência somente da Igreja. Do mesmo modo, reforçava a importância que ele agregava a esse tipo de instituição no campo educativo.

A relevância dos Seminários não era uma unanimidade entre o grupo de padres que defendia a realização de reformas no campo eclesiástico via legislativo, do qual Bhering fazia parte. Segundo Françoise Souza, para a moralização do clero, Diogo Feijó, apoiado pelos padres que ficaram conhecidos como o "grupo paulista", "preferiram deixar de lado as orientações tridentinas de valorização dos seminários, pois se opunham aos métodos de formação clerical aplicado em internatos, onde os candidatos ao sacerdócio isolavam-se do mundo." ${ }^{69} \mathrm{De}-$ fendiam que a formação educacional dos mesmos deveria ser iniciada pelos párocos e para complementar o ensino seriam organizadas "conferências eclesiásticas" nas paróquias. Com esse modelo, o grupo reproduzia a educação que havia recebido em São Paulo, "isto é, uma formação ilustrada, que prezava a moral e a disciplina religiosa, mas

${ }^{68}$ SOUZA, Françoise. Op. Cit. p. 382

${ }^{69}$ Idem, p. 381 
que, ao mesmo tempo preparava os sacerdotes para viverem integrados e atuantes na sociedade." 70

Se comparado com o "grupo paulista", Ribeiro Bhering diferia-se em relação ao tipo de estabelecimento destinado à formação eclesiástica, pois defendia que ela continuasse ocorrendo nos Seminários diocesanos. Contudo, não se distanciava do modelo de formação propriamente dito. $\mathrm{O}$ que queremos dizer é que ele também advogava em favor da formação de padres que fossem atuantes política, social e culturalmente, e não um segmento destacado da sociedade civil. Ensinamentos que preparassem os indivíduos para contribuir com o "progresso da nação" e com a "ordem pública" eram importante a todos os homens, fossem aspirantes a carreira eclesiástica ou não. Sua própria trajetória enquanto eclesiástico, professor, político e jornalista pode ser tomada como exemplo dessa percepção.

Outro ponto que merece ser explorado no argumento de Ribeiro Bhering consiste no fato dos eclesiásticos deverem submissão em primeira instância à monarquia brasileira. No jornal $O$ Novo Argos, ele enfatizava que entre as missões que lhe seriam reservadas enquanto escritor público destacava-se a de "censurar com toda prudência possível àquelas autoridades que pouco afetas a causa da nação ousam tocar com mão sacrílega na Arca Santa da constituição."71 Do mesmo modo, caberia ao escritor do jornal a função de repreender com moderação os "empregados públicos" que não desempenhassem bem a função que lhes era reservada na sociedade. O bispo diocesano, assim como o comandante das armas e o presidente da província, estava entre as autoridades que devido ao importante cargo ocupado deveria ter suas ações constantemente monitoradas.

Foi o que ocorreu com Frei José, seus feitos foram foco de frequente vigília e de recorrentes censuras. Em uma delas o prelado foi repreendido por estar ordenando candidatos ao sacerdócio sem que estes

\footnotetext{
${ }^{70}$ Idem, p. 381

${ }^{71}$ O NOVO ARGOS. Ouro Preto: Tipografia do Universal, nº 1, 1829.
} 
tivessem manifestado publicamente adesão ao pacto social brasileiro. "Sendo o Ministério Eclesiástico em nossa opinião e na de grandes homens Emprego Público, não se deve conferir ordens aqueles que não tiverem jurado a Constituição."72 Tal juramento deveria ser comprovado mediante um certificado assinado pela Câmara municipal de Mariana. Bhering julgava "muito prudente esta advertência, até porque S. Rmo por esta maneira mostraria ao público, que os clérigos são constitucionais de coração e por obrigação." ${ }^{.73}$

Além dos eclesiásticos serem obrigados a manifestar adesão a Constituição, Ribeiro Bhering defendia que o Seminário de Mariana deveria ser um local que poderia ser desfrutado por "qualquer indivíduo desejoso de se instruir." 74 A instituição não poderia estar submetida às vontades e partidarismos do prelado que estivesse em seu comando, e sim seguir as legislações e projetos educacionais discutidos nos gabinetes estatais. Não só considerava os eclesiásticos funcionários da monarquia, como assegurava que os bens de raízes da Igreja, em sua maioria herdado, deveriam estar a serviço da nação e do bem público. No trecho que segue, publicado no jornal $O$ Universal, respondeu ao redator do Telégrafo, designado como "J.C." acerca da doação do prédio onde estava instalado o colégio episcopal de Mariana.

72 O NOVO ARGOS. Ouro Preto: Tipografia do Universal, nº 5, 1829.

73 Idem

${ }^{74}$ Somando-se a outras vozes, Ribeiro Bhering clamava pelo "urgente derramamento da instrução" no Brasil. Nunca é demais problematizar as condições de acesso à educação no Brasil imperial. Para o historiador Ilmar de Mattos, a distribuição do ensino se entrecruzava com a organização da sociedade marcadamente hierarquizada, a qual os grupos dirigentes desejavam ver mantida. $\mathrm{O}$ princípio da "universalidade do ensino" não pressupunha igualdade de oportunidade, legitimando, portanto, a permanência das diferenças sociais agravadas pelo sistema escravista. Enquanto para os jovens abastados encontravam-se disponíveis cursos como os Jurídicos e de Medicina, ao "povo miúdo" era reservado o ensinamento de "padrões de civilidade" e de conteúdos que aperfeiçoasse e disciplinasse suas atividades profissionais. MATTOS, Ilmar Rohloff de. O tempo saquarema. São Paulo: Hucitec, 2004. No entanto, tais isso não foi suficiente para impedir que "grupos subalternos" tenham criado, a partir de seus próprios interesses, espaços e redes de sociabilidade capazes de lhes garantir acesso à educação e a condições de trabalho mais favoráveis. Sobre o assunto ver: MACCORD, Marcelo. Artífices da Cidadania. Mutualismo, educação e trabalho no Recife oitocentista. Campinas: Editora da Unicamp, 2012. 
O Seminário J. C., é do público: o doador, que mimoseou o público com prédios rústicos, e urbanos, que formam o patrimônio do Seminário, teve por fim na sua doação o bem público, e não a opulência da Mitra. Se o Sr. Tesoureiro de ausentes, que representa os herdeiros do finado doador lesse a escritura de doação, [...] e então J. C. veria de quem é o Seminário. ${ }^{75}$

Antonio José Ribeiro Bhering depositava confiança no poder Legislativo e na possibilidade de alterar por seu meio o que dizia respeito à vida em sociedade. Assim, não teria problema, em sua concepção, que as normas de regência do Seminário, a escolha dos mestres e os conteúdos ensinados fossem definidos nos limites das leis. Ele não se encontrava sozinho nessa percepção. A ideia de que os espaços religiosos poderiam ser organizados e reformados por meio do Legislativo foi compartilhada pela maioria dos eclesiásticos que tiveram destacada atuação política no período, como dito no tópico anterior. Por fim, é importante dizer que embora Ribeiro Bhering tenha conseguido expor suas proposições acerca dos Estatutos do Seminário no Conselho provincial e na imprensa, elas não foram acatadas pelo bispo. Permaneceu valendo até a sua morte, e mesmo no episcopado seguinte, a supremacia da diocese e do prelado nos assuntos do colégio.

\section{Considerações finais}

O Seminário de Mariana era uma referência educacional em Minas Gerais, o que justifica, ao menos em parte, o fato de ter sido tomado como espaço de disputas. Instalado na sede do bispado mineiro e tido como a primeira "casa de instrução" da localidade, o colégio contribuiu para que a cidade de Mariana ostentasse não somente o status de centro religioso, mas também o de centro educacional da província. Desde sua criação, destinava-se não só para formação de padres, mas oferecia também ensino secundário, sobretudo aulas de humanidades, a quem tivesse condições de custear os estudos. Deste modo, não tinha uma função estritamente religiosa, mas se projetava

${ }^{75}$ O UNIVERSAL. Ouro Preto: Tipografia do Universal, n 357, 1829. 
como um local frequentado pelos jovens que seguiriam carreiras em outras áreas. Essa dupla atribuição relaciona-se ao recorrente envolvimento do setor eclesiástico com as práticas educativas, aspecto de longa duração na história brasileira.

Entre as décadas de 1820 e 1830, verificou-se em Minas Gerais o anseio de regular a educação oferecida à mocidade. Propunha-se, sobretudo no Conselho Geral da província e nos espaços públicos de sociabilidade, a criação de aulas, que iam das primeiras letras ao ensino de ciências, e a reforma das instituições educacionais já existentes. Não era esse um debate regional, em outras províncias e na Corte a temática também era foco de debates. A difusão de conhecimentos e valores específicos era vislumbrada pelas elites políticas como uma possibilidade de inserir o Brasil entre as nações "cultas e civilizadas", preparar homens para atuar na vida pública (seja no campo político, econômico ou religioso), garantir a coesão social e manter a ordem. Posto isto, o Estado brasileiro começou a se inserir em uma área que os eclesiásticos atuavam de maneira preponderante. Se, por um lado, o poder público não desconsiderou a importância dos religiosos e de seus colégios no processo educativo, por outro, consolidou-se conflitos de jurisdição entre essas duas instâncias.

Em relação ao Seminário de Mariana, as cobranças e propostas provenientes do Conselho provincial, algumas vezes endossadas pela Assembleia Geral Legislativa, foram qualificadas por Dom Frei José como "intromissões em assuntos religiosos". Para o bispo, a administração do estabelecimento, bem como a definição de suas regras de regência, conteúdos e a nomeação de mestres era um direito exclusivo seu. Para tornar seu discurso legítimo, recorreu a autoridades ligadas a Santa Sé, onde considerava residir à soberania eclesiástica, e a religiosos brasileiros que se opunham a interferência do poder público no que consideravam ser de competência da Igreja.

Antonio José Ribeiro Bhering, por sua vez, colocava em outro patamar as relações entre os poderes. Para ele, os eclesiásticos e suas instituições deveriam estar submissos à monarquia brasileira. Diante disso, as reformas realizadas em espaços institucionais regidos por eclesiásti- 
cos deveriam ser aprovadas pelo poder público. Essa visão o fez considerar a reformulação realizada por Dom Frei José nos Estatutos do Seminário como inconstitucionais, pois além do bispo não ter solicitado permissão para alterá-los, ele se recusava a publicizar o documento. No mais, Ribeiro Bhering considerava que o colégio deveria estar disponível para receber aulas determinadas pelo Conselho provincial.

Longe de estar isolado na cidade de Mariana, o conflito estabelecido entre a mais alta autoridade eclesiástica de Minas Gerais e um "padre político" vinculavam-se à dilemas mais amplos surgidos nas décadas iniciais do processo de construção do Estado e da nação brasileiros. A redefinição dos campos de atuação dos poderes políticos e religiosos não foi tarefa simples e se prolongou ao longo de todo o Oitocentos, envolvendo diferentes atores sociais e instituições nacionais e internacionais.

\section{Referências Bibliográficas}

\section{Fontes}

\section{Arquivo Eclesiástico da Gúria de Mariana (AECM):}

AECM: Arquivo 2; gaveta 2; pasta 2

AECM: Arquivo 2, gaveta2, pasta 36

AECM: Arquivo 2, gaveta 2, pasta 8

AECM: Arquivo 2; Gaveta 2; Pasta 9

\section{Arquivo Público Mineiro (APM), Belo Horizonte/MG:}

APM: Fundo Conselho Geral da Província, Notação GGP 3/1 Cx. 03

APM: Fundo Conselho Geral da Província, Notação CGP-03

APM: Fundo Conselho Geral da Província, Notação GGP-07

O UNIVERSAL. Ouro Preto: Tipografia do Universal, 1825-1842. Disponível em: http://www.siaapm.cultura.mg.gov.br/

\section{Biblioteca Nacional (BN), Rio de Janeiro/RJ:}

O NOVO ARGOS. Ouro Preto: Tipografia do Universal, 1829 a 1834. Reprodução do microfilme: PR SOR 01827/PRSOR 01828. 
O HOMEM SOCIAL. Mariana: Tipografia Marianense, 1832-1834. Reprodução do microfilme: PR SOR 01827/PRSOR 01828.

\section{Bibliografia}

ACGIOLY, Hildebrando. Os Primeiros Núncios no Brasil. São Paulo: Instituto Progresso Editorial, 1949.

ALMEIDA, Gabriela. Jogos de Poderes: o Seminário de Mariana como espaço de disputas políticas, religiosas e educacionais (1821-1835). Dissertação (Mestrado em História) Instituto de Filosofia e Ciências Humanas, Universidade Estadual de Campinas, Campinas, 2015.

AZZI, Riolando. O Altar Unido ao Trono. Um projeto conservador. São Paulo: Edições Paulinas, 1992.

. Os bispos religiosos durante a época imperial no Brasil. Revista Convergências, ano IX, nº 92, maio de 1976.

BERSTEIN, Serge. A Cultura Política. In: RIOUX, Jean-Pierre \& SIRINELLI, Jean-François. Para uma História Cultural. São Paulo: Estampa, 1998.

CARVALHO, José Murilo; NEVES, Lúcia B. (orgs.). Repensando o Brasil do Oitocentos. Rio de Janeiro: Civilização Brasileira, 2009.

GARVALHO, José Murilo. Nação e cidadania no Império: novos horizontes. Rio de Janeiro: Civilização Brasileira, 2007.

CARRATO, Luiz Ferreira. Igreja, Iluminismo e Escolas Mineiras Coloniais. São Paulo: Cia. Editora Nacional/ Edusp, 1968.

DORNAS FILHO, João. O Padroado e a Igreja Brasileira. São Paulo: Nacional, 1938.

FERNANDES, Renata Silva. O governo das províncias do Império do Brasil: os Conselhos de Governo e os Conselhos Gerais de província nos debates parlamentares (1823-1834). Dissertação (Mestrado em História). Instituto de Ciências Humanas, Universidade Federal de Juiz de Fora, Juiz de Fora, 2014.

GOUVÊA, Maria de Fátima S. O Império das províncias. Rio de Janeiro, 1822-1889. Rio de Janeiro: Givilização Brasileira/FAPERJ, 2008.

GRINBERG, Keila; SALLES, Ricardo (org.). O Brasil Imperial Vol. I, II e III. Rio de Janeiro: Civilização Brasileira, 2009. 
HESPANHA, António Manuel. Governo, elites e competência social: sugestões para um entendimento renovado da história das elites. In: BICALHO, Maria Fernanda; FERLINI, Vera Lucia (orgs). Modos de Governar: ideias e práticas políticas no Império Português (séculos XVI a XIX). São Paulo: Alameda, 2005.

HAUCK, João Fagundes; et all. História da Igreja no Brasil: Ensaio de interpretação a partir do povo - Segunda Época: A Igreja no Brasil do século XIX. $3^{a}$ edição. Petrópolis: Edições Paulinas / Vozes, 1992.

JANCSÓ, István (org). Brasil: Formação do Estado e da Nação. São Paulo-Ijuí: Hucitec-Fapesp, 2003.

JANCSÓ, István; PIMENTA, João Paulo Garrido. Peças de um mosaico (ou apontamentos para o estudo da emergência da identidade nacional brasileira). In: MOTA, Carlos Guilherme (org.). Viagem incompleta. A experiência brasileira (1500-2000). Formação: histórias, 2. ed. São Paulo: SENAC, 2000.

LUSTOSA, Oscar de Figueiredo. Reformismo da Igreja no Brasil Império: do Celibato à Caixa Eclesiástica. São Paulo: Loyola, 1985.

LUZ, Estevão Marcondes. Incendiárias folhas: ação política e periodismo na trajetória do padre Antônio José Ribeiro Bhering (1829-1849). Tese (Doutorado em História). Faculdade de Ciências Humanas e Sociais, Unesp, Franca, 2016.

MOLINA, Sandra Rita, Des(Obediência), Barganha e Confronto: A Luta da Província Carmelita Fluminense pela Sobrevivência (1780-1836). Dissertação (Mestrado em História). Instituto de Filosofia e Ciências Humanas, Universidade Estadual de Campinas, Campinas, 1998.

MOREL, Marco. As transformações dos Espaços Públicos. Imprensa, atores Políticos e Sociabilidade na Cidade Imperial. São Paulo: Hucitec, 2003.

PEREIRA, Mabel Salgado. Romanização e Reforma Ultramontana: Igreja Católica em Juiz de Fora. Juiz de Fora: Irmãos Justinianos, 2004.

RICGI, Magda Maria de Oliveira. Assombrações de um padre regente: Diogo Antônio Feijó (1784-1843). Campinas: Editora da UNICAMP, 2002.

SANCHIS, Pierre. "Os Brasis" da Igreja Brasileira. Revista Geraes, n. 46, 1987.

SCHIAVINATTO, Iara Lis Franco. Pátria Coroada. O Brasil como corpo político autônomo, 1780-1831. São Paulo: Editora Unesp, 1999. 
SILVA, Wlamir. Liberais e o povo. A construção da hegemonia liberal-moderada na província de Minas Gerais (1830-1834). São Paulo: Hucitec, 2009.

SOUZA, Françoise Jean de Oliveira. Do Altar à Tribuna. Os Padres Políticos na Formação do Estado Nacional Brasileiro (1823-1841). Tese (Doutorado em História). Centro de Ciências Humanas e Sociais, Universidade Estadual do Rio de Janeiro, Rio de Janeiros, 2010.

TRINDADE, Raimundo. Breve Notícia dos Seminários de Mariana. Mariana: Editada sob os auspícios da Arquidiocese de Mariana, 1951.

VILLALTA, Luiz Carlos. Educação: nascimento, haveres e gênero. In: RESENDE, Maria Efigênia Lage de; VILLALTA, Luiz Carlos (orgs.). História das Minas Setecentistas. Belo Horizonte: Autêntica, 2007.

. A "Torpeza Diversificada dos Vícios": Celibato, Concubinato e Casamento no Mundo dos Letrados de Minas Gerais (1748-1801). Dissertação (Mestrado em História Social). Faculdade de Filosofia, Letras e Ciências Humanas, Universidade de São Paulo, São Paulo, 1993.

ZANON, Dalila. O poder dos bispos na administração do ultramar português: o bispado de São Paulo entre 1771 e 1824. Tese (Doutorado em História). Instituto de Ciências Humanas e Sociais, Universidade Estadual de Campinas, 2014.

WERNET, Augustin. A Igreja Católica no século XIX. A Reforma de D. Antônio Joaquim de Melo (1851-1861). São Paulo: Editora Ática, 1987.

A Igreja Paulista no Século XIX. São Paulo: Ática, 1987.

Recebido: 24/04/2017 - Aprovado: 02/11/2017 